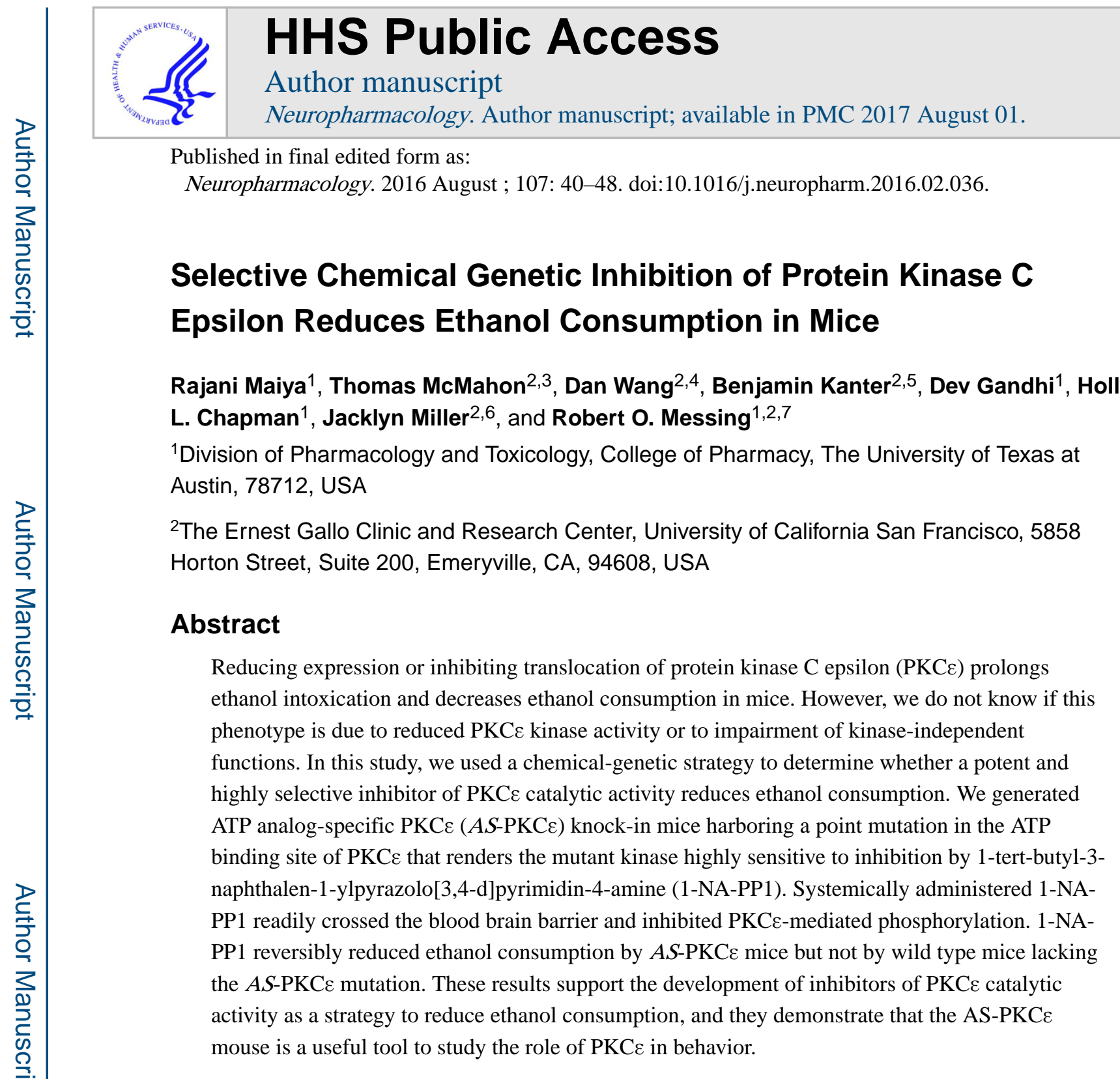

Keywords

protein kinase C; alcohol; ethanol; 1-NA-PP1; $A S$-kinase

\footnotetext{
${ }^{7}$ Corresponding author: Robert O. Messing, MD, UT Austin College of Pharmacy, C0875, 107 W. Dean Keeton, BME6.116A, Austin, TX 78712, Phone: 512-471-1735 Fax: 512-471-9272 romessing@ austin.utexas.edu.

3 Present Address: UCSF Neurology, Box 2911, 1550 4th Street, Bldg. 19B Room 546, San Francisco, CA 94158, USA.

${ }_{5}^{4}$ Present Address: UCSF Neurology, Box 1207, 675 Nelson Rising Lane, Room 292, San Francisco, CA 94158, USA.

5 Present Address: Kavli Institute for Systems Neuroscience and Centre for Neural Computation, Norwegian University of Science and Technology, Olav Kyrres Gate 9, MTFS, 7489 Trondheim, Norway.

6Present Address: USDA Agricultural Research Service, Foodborne Toxin Detection and Prevention, 800 Buchanan St, Albany, CA 94710, USA.
}

Publisher's Disclaimer: This is a PDF file of an unedited manuscript that has been accepted for publication. As a service to our customers we are providing this early version of the manuscript. The manuscript will undergo copyediting, typesetting, and review of the resulting proof before it is published in its final citable form. Please note that during the production process errors may be discovered which could affect the content, and all legal disclaimers that apply to the journal pertain.

Conflicts of interest: R.O.M. is an inventor on U.S. Patent No. US 8,785,648 B1 entitled PKC-Epsilon Inhibitors, awarded July 22, 2014. None of the other authors of this manuscript have any financial conflicts to disclose. 


\section{Chemical compounds}

1-tert-butyl-3-naphthalen-1-ylpyrazolo[3,4-d]pyrimidin-4-amine

\section{Introduction}

Alcohol use disorder (AUD) is highly prevalent and incurs great cost to society (Rehm et al., 2009). Despite this fact, there are currently only three drugs approved in the U.S to treat AUD: Disulfuram, naltrexone, and acamprosate (Johnson, 2008). Although all are effective, disulfuram is only useful for short-term treatment of highly motivated patients in supervised settings, while naltrexone and acamprosate suffer from compliance issues and small effect sizes (Johnson, 2008). Hence, there is considerable need to develop novel therapies to combat alcoholism.

Studies from our laboratory suggest that protein kinase $\mathrm{C}$ epsilon $(\mathrm{PKC} \varepsilon)$ is a target for development of drugs to reduce ethanol consumption. Previous studies found that $\mathrm{Prkce}^{-/-}$ mice drink substantially less ethanol than wild type mice (Hodge et al., 1999) and show heightened aversion to ethanol (Newton and Messing, 2007), possibly because of impaired acute functional tolerance to its ataxic and hypnotic effects (Wallace et al., 2007). These behaviors do not result from developmental changes since inducible transgenic expression of PKC $\varepsilon$ in the amygdala and striatum restores normal sensitivity to intoxication and increases drinking in $\mathrm{Prkce}^{-/-}$mice to levels observed in wild type mice (Choi et al., 2002). Moreover, knockdown of PKC $\varepsilon$ in the amygdala by RNA interference (Lesscher et al., 2009) or inhibition by a peptide designed to block translocation of activated PKC $\varepsilon$ (Cozzoli et al., 2015 ) reduces ethanol consumption in adult wild type mice. PKC $\varepsilon$ may modulate ethanol intoxication and consumption through phosphorylation of at least 2 substrates: $\mathrm{GABA}_{\mathrm{A}} \gamma^{2}$ subunits at Ser-327 (Qi et al., 2007) and the N-ethylmaleimide sensitive factor at Ser-460 and Thr-461 (Chou et al., 2010). However, all of the evidence implicating PKC $\varepsilon$ in behavioral responses to ethanol is derived entirely from genetic or shRNA-mediated reductions in $\mathrm{PKC} \varepsilon$ expression or use of a peptide translocation inhibitor. The effect of selective, pharmacological inhibition of PKC $\varepsilon$ kinase activity with a small molecule inhibitor has not been tested. Such studies are needed to determine if $\mathrm{PKC} \varepsilon$ is a viable drug candidate for the treatment of alcohol use disorder.

Unfortunately, there are no compounds currently available to selectively inhibit the catalytic activity of PKCE. To circumvent this problem, we have used a chemical-genetic approach to study kinase inhibition by selective, cell-permeable, small molecule inhibitors. The strategy targets the ATP-binding pocket conserved in all kinases, replacing a bulky gatekeeper residue with an alanine or glycine to generate mutant alleles that can utilize ATP analogs in addition to ATP, and that are uniquely sensitive to novel kinase inhibitors, such as analogs of PP1 (Bishop et al., 2001). We have generated such an ATP analog-sensitive PKCE ( $A S$ $\mathrm{PKC} \varepsilon$ ) carrying the mutation M486A and have used it successfully to probe PKC $\varepsilon$ function in cell lines (Durgan et al., 2008, Qi et al., 2007). Here, we report the generation of an $A S$ $\mathrm{PKC} \varepsilon$ knock-in mouse to examine the effects of $\mathrm{PKC} \varepsilon$ on behavior. Using the $A S$-kinase inhibitor 1-Naphthyl-PP1 (1-NA-PP1) and $A S$-PKC $\varepsilon$ mice, we found that selective 
inhibition of $A S$-PKC $\varepsilon$ prolongs the ataxic and hypnotic effects of ethanol and reduces ethanol consumption. These results are consistent with our previous findings in $\mathrm{Prkce}^{-/-}$ mice (Choi et al., 2002, Hodge et al., 1999) and validate PKC $\varepsilon$ as a candidate for drug development, while demonstrating the utility of the $A S$-PKC $\varepsilon$ mouse as a useful tool for investigating the role of $\mathrm{PKC} \varepsilon$ in behavior.

\section{Materials and methods}

\subsection{Generation of $A S-P K C \varepsilon$ mice}

Knock-in mice were generated by Caliper Discovery Alliances and Services (Hanover, MD). The Ensembl database was used to identify the BAC clone RP23-75J18 containing the genomic sequence of mouse chromosome 17 from nt \# 86451480 to 86613962 . This sequence includes the exon encoding Prkce M486. 5' arm ( 1.9 kb) and 3' homology arms $(\sim 6.0 \mathrm{~kb})$ were generated by PCR and cloned into the targeting vector pLoxNwCD, which contains a floxed neo expression cassette for positive selection and a DTA expression cassette for negative selection. The M486A mutation was introduced into the $5^{\prime}$ arm by sitedirected mutagenesis. The final vector was confirmed by restriction digestion and end sequencing analysis, and then linearized and electroporated into C57BL/6 ES cells. Approximately 192 ES clones that survived selection were screened using a 5' external probe and 4 clones were expanded. Southern analysis of the ES cell DNA using 5' external, 3' external and neo cassette probes identified three correctly aligned clones with a single neo insertion. Two were transfected with Cre recombinase and one was confirmed to be neo deleted by PCR. Presence of the mutation in that clone was confirmed by PCR and sequencing. These ES cells were injected into tyrosinase deficient blastocysts and transplanted into pseudo-pregnant mice. Germ line transmission of the mutation from chimeras was confirmed by PCR using the following primers; CAGCACGGAGTGATCTACAGGTATTCTC (forward primer) and CGGACACAAACAGCAGGTCAAATCT (reverse primer). Heterozygous mutant progeny were then intercrossed to generate homozygous $A S$-PKC $\varepsilon$ mice, which were subsequently intercrossed and maintained as an inbred line on a C57BL/6NTac background. Mice used for experiments were housed under a reverse light dark cycle (lights off at 10AM; lights on at 10PM). Only male mice were tested so that we could compare results with prior studies that used male Prkce $^{-/}$mice (Choi et al., 2002, Hodge et al., 1999). All procedures followed the National Institutes of Health Guide for Care and Use of Laboratory Animals (IH Publications No. 8023, revised 2011) and were approved by the Institutional Animal Care and Use Committees of the Ernest Gallo Clinic and Research Center and the University of Texas at Austin. All efforts were made to minimize animal suffering and to reduce the number of animals used in experiments.

\subsection{Administration of 1-NA-PP1}

1-NA-PP1 was obtained from Dr. Kevin Shokat (UCSF) or from Tocris Biosciences (Bristol, UK). For ethanol, saccharin, and quinine consumption studies, we dissolved 1-NA-PP1 in $100 \%$ DMSO at 20 or $30 \mathrm{mg} / \mathrm{ml}$ and then diluted it 20 -fold in deionized water containing $10 \%$ Tween-80 with sonication. For studies using oral administration, we prepared 1-NAPP1 as a $100 \mathrm{mM}$ stock solution in $100 \%$ DMSO by gentle heating and sonication. This 
stock was diluted to $500 \mu \mathrm{M}$ in water containing $1 \%$ cremophor-RH40 (Sigma-Aldrich, St. Louis, MO) and 2g/L sucralose (Sigma-Aldrich) to increase palatability. Control animals received an equivalent amount of DMSO vehicle in cremophor-sucralose-water. 1-NA-PP1 food pellets $(1 \mathrm{~g} / \mathrm{kg}$ ) were obtained from Research Diets (New Brunswick, NJ). Control food pellets contained an equivalent amount of vehicle (DMSO). To determine the effects of 1NA-PP1 on protein phosphorylation, we dissolved 1-NA-PP1 in vehicle containing 5\% DMSO and 20\% Cremophor EL (Sigma-Aldrich).

\subsection{Western blot analysis}

Animals were sacrificed with $\mathrm{CO}_{2}$ asphyxiation or cervical dislocation and the amygdala and striatum were rapidly dissected on ice. Brain regions were homogenized with a glass Dounce homogenizer using 20 strokes in $0.1-0.5 \mathrm{ml}$ of ice-cold extraction buffer $(25 \mathrm{mM}$ HEPES - pH7.8, 300mM NaCl, $1.5 \mathrm{mM} \mathrm{MgCl}_{2}, 1 \%$ Triton X-100, 0.1mM DTT) containing Phosphatase Inhibitor 1 and 3 (Sigma-Aldrich) and Protease inhibitor Complete ${ }^{\mathrm{TM}}$ (Roche Diagnostics USA, Indianapolis, IN.). Lysates were clarified by centrifugation at $10,621 \times \mathrm{g}$ for 15 minutes at $4{ }^{\circ} \mathrm{C}$ and then resolved by SDS-PAGE using 4-12\% gradient gels (Invitrogen, Carlsbad, CA). Proteins were transferred to nitrocellulose membranes which were blocked with Tris buffered saline (TBS: $50 \mathrm{mM}$ Tris, $\mathrm{pH} 7.6,150 \mathrm{mM} \mathrm{NaCl}$ ) containing $0.1 \%$ Tween-20 (TBS-T) and 5\% BSA. The blots were incubated with anti-phospho-GABA $\gamma 2-\mathrm{S}(\mathrm{P}) 327$ antibody (Qi et al., 2007) at 1:1000 dilution in 5\% BSA overnight at $4{ }^{\circ} \mathrm{C}$. Blots were washed 3 times in TBS-T, 8 minutes per wash, incubated in horseradish peroxidaseconjugated goat anti-rabbit IgG antibody (Jackson ImmunoResearch, West Grove, PA; 1:1000 in 5\% nonfat dry milk) for $1 \mathrm{~h}$ at room temperature, washed again, and visualized using the SuperSignal West Pico Chemiluminescent Substrate kit (Thermo Fisher, Waltham, MA). Immunoreactive bands were quantified by densitometric scanning using Image $\mathbf{J}$ (Schneider et al., 2012). Blots were stripped and re-probed with total $\mathrm{GABA}_{\mathrm{A}} \gamma 2$ antibody (Alamone labs, Jerusalem, Israel; 1:1000 dilution) or GAPDH (Cell Signaling, Danvers, MA; 1:10,000 dilution).

\subsection{Behavioral screen}

We examined mice for morphological abnormalities, startle response, righting reflex, and body weight (Crawley, 2008). Strength was measured using the hanging wire test. Motor learning and coordination were assessed as in prior work (Lee et al., 2013) using a rotarod treadmill (AccuRotor Rota-Rod; Omnitech Electronics, Columbus, $\mathrm{OH}$ ) that accelerated from 0 to $40 \mathrm{rpm}$ in $5 \mathrm{~min}$. Locomotor activity was recorded as the distance traveled in an open field chamber over 60 min (Hodge et al., 1999). Anxiety-like behavior was measured using an elevated plus maze as in previous work (Hodge et al., 2002). Thermal sensation was tested using a tail-flick apparatus (Columbus Instruments, Columbus, $\mathrm{OH}$ ).

\subsection{Ethanol, saccharin, and quinine consumption}

Continuous access two-bottle choice drinking was performed as described previously (Lim et al., 2012). Once a stable level of drinking of $10 \%$ ethanol was achieved, mice were habituated to 3 intraperitoneal injections of vehicle. The effects of 1-NA-PP1 on drinking were studied using a within-subjects design, under which each animal received vehicle, 20, or 30mg/kg 1-NA-PP1 on different days. 1-NA-PP1 was administered 5-10 min before the 
onset of the dark cycle. The amount of ethanol and water consumed was monitored for 48 hours after injection. Ethanol preference was calculated by dividing the amount of ethanolcontaining solution consumed by total fluid intake. Mice were allowed to recover for 1-2 days between doses of 1-NA-PP1.

Following the ethanol consumption procedure mice were tested for two-bottle choice saccharin $(0.03 \%$ then $0.06 \%)$ and quinine $(0.015,0.03$ and $0.06 \mathrm{mM})$ consumption. Each concentration of saccharin was presented for 4 or 5 days. After 2 days of exposure to $0.06 \%$ saccharin, mice were habituated to 2 intraperitoneal injections of vehicle. The effect of 1NA-PP1 on saccharin consumption was tested using a within-subjects design as outlined for the ethanol consumption study. Mice were then allowed to consume water containing increasing concentrations of quinine. After exposure to $0.06 \mathrm{mM}$ quinine for 2 days, mice were habituated to 2 vehicle injections and then administered 1-NA-PP1 in a within-subjects design.

\subsection{Responses to acute ethanol administration}

Ethanol-induced ataxia was evaluated as described (Wallace et al., 2007) with the rotarod treadmill set to a fixed speed of $6 \mathrm{rpm}$. The ethanol-induced loss of the righting reflex was examined as described in prior work (Choi et al., 2002, Hodge et al., 1999, Lee et al., 2014, Wallace et al., 2007).

\subsection{Ethanol clearance}

Mice were administered $4 \mathrm{~g} / \mathrm{kg}$ of ethanol intraperitoneally and the $20 \mu \mathrm{l}$ of blood were obtained via tail puncture at $30,60,90,120$, and 180 min post-injection. Blood samples were stored at $-80^{\circ} \mathrm{C}$, until BECs were determined using an NAD-ADH enzymatic assay (Carnicella et al., 2009).

\subsection{Statistical Analysis}

Data were analyzed using Prism 6.0e (GraphPad Software, La Jolla, CA). Data were expressed as mean \pm SEM values and analyzed by two-tailed $t$-test or repeated measures ANOVA with post-hoc Dunnet's multiple comparisons test as appropriate.

\section{Results}

\subsection{Generation of AS-PKC\& mice}

$A S$-PKCE mice were generated by altering the sequence of exon 11 in the Prkce gene to encode the M486A mutation (Fig. 1A and B). Homozygous $A S$-PKC $\varepsilon$ and wild type C57BL/6N mice showed similar abundance and pattern of PKC $\varepsilon$ immunoreactivity in the brain (Figs. 1C and D). $A S$-PKC $\varepsilon$ mice were like wild type littermates in appearance and home cage behavior, and showed a similar startle response and righting reflex. They were also like wild type animals in other behaviors including open field exploration, anxiety likebehavior on the elevated plus maze, hot plate tail-flick latency, ability to remain on an accelerating rotarod, and ability to hang suspended from a wire (Table 1). These results indicate that the PKC $\varepsilon$ M486A knock-in mutation did not disrupt development or baseline behavior. 


\subsection{Pharmacokinetics of 1-NA-PP1}

To determine the abundance and half-life of 1-NA-PP1 in plasma and brain, a pharmacokinetic study was performed following intraperitoneal administration of $30 \mathrm{mg} / \mathrm{kg}$ 1-NA-PP1 in 5\% DMSO and 10\% Tween-80 to wild type C57BL/6J mice (Fig. 2A). Plasma levels of 1NA-PP1 reached $7.3 \pm 0.43 \mu \mathrm{M}$ thirty minutes after injection and declined biphasically $\left(\mathrm{R}^{2}=0.94\right)$ with half-lives of 0.47 and 11.62 hours (Fig. 2A). Brain levels reached $2167 \pm 85 \mathrm{ng} / \mathrm{g}(\sim 6.8 \pm 0.27 \mu \mathrm{M})$ one hour after injection and declined in a singlephase $\left(\mathrm{R}^{2}=0.93\right)$ with a half-life of 0.57 hours (Fig. 2B). These results indicate that 1-NAPP1 enters the brain rapidly and efficiently after intraperitoneal administration and achieves concentrations predicted to inhibit $A S$-PKC $\varepsilon(K \mathbf{i}=18.7 \mathrm{nM})$ based on in vitro studies (Qi et al., 2007).

Plasma and brain concentrations of 1-NA-PP1 were also determined following repeated oral administration. Wild type C57BL/6N mice were provided food pellets containing $1 \mathrm{~g} / \mathrm{kg} \mathrm{1-}$ NA-PP1 and water containing 500 $\mu \mathrm{M} 1-\mathrm{NA}-\mathrm{PP} 1$ in 1\% Cremophor-RH40 and 0.2\% sucralose. Control animals were fed food and water containing the corresponding vehicles. Mice were sacrificed after 3 days and the concentration of 1-NA-PP1 was determined by LC-MS/MS. Oral administration of 1-NA-PP1 yielded a plasma concentration of 117 $\pm 23 \mathrm{nM}(\mathrm{n}=5)$ and brain concentration of $140 \pm 54 \mathrm{ng} / \mathrm{g}$ protein $(\sim 441 \pm 172 \mathrm{nM} ; \mathrm{n}=5)$. These results indicate that repeated administration of 1-NA-PP1 in food and water leads to levels of 1-NA-PP1 in the brain and plasma predicted to inhibit $A S$-PKCE (Qi et al., 2007).

To determine whether systemic administration of 1-NA-PP1 inhibits $A S$-PKCE-mediated phosphorylation in the brain, we examined phosphorylation of the $\mathrm{GABA}_{\mathrm{A}}$ receptor $\gamma 2$ subunit since we previously found that PKCe phosphorylates this subunit at S327 (Qi et al., 2007). We administered 1-NA-PP1 by intraperitoneal injection rather than orally in this experiment to better control the dosage relative to the timing of tissue collection. $A S$-PKC $\varepsilon$ mice were administered 25mg/kg 1-NA-PP1 or vehicle and sacrificed 1 hour later. Although we used a different vehicle (5\%DMSO/20\% Cremophor-EL) to dissolve 1-NA-PP1 for this experiment, pharmacokinetic analyses after intraperitoneal injection of $30 \mathrm{mg} / \mathrm{kg} 1-\mathrm{NA}-\mathrm{PP} 1$ in this vehicle revealed plasma $(6.47 \pm 0.25 \mu \mathrm{M} ; \mathrm{n}=2)$ and brain concentrations (2055 $\pm 455 \mathrm{ng} / \mathrm{g} ; \sim 4.43 \pm 2.03 \mu \mathrm{M} ; \mathrm{n}=2$ ) similar to those observed for 1-NA-PP1 dissolved in $5 \% \mathrm{DMSO} / 10 \%$ Tween-80. Compared with vehicle-injected mice, there was a 33\% reduction in $\gamma 2-\mathrm{S}(\mathrm{P}) 327$ phosphoimmunoreactivity in the striatum of 1-NA-PP1-treated mice (Fig. 3).

\subsection{1-NA-PP1 reduces ethanol consumption by AS-PKC $\varepsilon$ mice}

To determine whether 1-NA-PP1 alters ethanol consumption, we subjected $A S$-PKC $\varepsilon$ mice to a continuous access, two-bottle choice-drinking procedure whereby the ethanol concentration was escalated from $3 \%$ to $6 \%$, and finally to $10 \%$ over 8 days. After mice were habituated to vehicle injections and had attained a stable level of drinking $10 \%$ ethanol for three consecutive drinking sessions $[\mathrm{F}(2,34)=1.474, P=0.2433$; Fig. 4A], they were administered 1-NA-PP1 using a within-subjects design in which all animals received vehicle or 1-NA-PP1 on different days. 1-NA-PP1 at 20 or $30 \mathrm{mg} / \mathrm{kg}$ reduced ethanol consumption during the first $24 \mathrm{~h}[\mathrm{~F}(2,34)=10.69 ; P=0.0003$; Fig. 4B]. This effect was reversible since ethanol consumption was similar $48 \mathrm{~h}$ after treatment with vehicle or 1-NA-PP1 $[\mathrm{F}(2,34)=$ 
3.058; $P=0.0601$; Fig. 4C $]$. 1-NA-PP1 did not significantly alter ethanol preference $[\mathrm{F}(2$, $34)=0.9508 ; P=0.3965 ;$ Fig. 4D]. Although there was a trend towards reduced water consumption at $30 \mathrm{mg} / \mathrm{kg}$, this effect was not statistically significant $[\mathrm{F}(2,34)=1.722 ; P=$ 0.1940; Fig. 4E].

To determine whether 1-NA-PP1 alters taste perception, we examined its effect on consumption of saccharin- and quinine-containing solutions. 1-NA-PP1 at $30 \mathrm{mg} / \mathrm{kg}$ significantly reduced saccharin consumption $[\mathrm{F}(2,26)=11.22 ; P=0.0003$; Fig. 4F $]$, but did not alter the amount of quinine consumed $[\mathrm{F}(2,26)=0.099 ; P=0.906$; Fig. $4 \mathrm{G}]$. These results suggest that at $30 \mathrm{mg} / \mathrm{kg}, 1-\mathrm{NA}-\mathrm{PP} 1$ affects perception of sweet, but not bitter taste.

To examine the possibility that 1-NA-PP1 reduced ethanol intake by altering ethanol metabolism, we measured clearance of ethanol administered to $A S$-PKC $\varepsilon$ mice 4 hours after intraperitoneal injection of $30 \mathrm{mg} / \mathrm{kg}$ 1-NA-PP1. Blood ethanol concentrations were measured every 30 minutes for 3 hours (Fig. 4H). 1-NA-PP1 did not significantly alter the time course of ethanol clearance $\left[\mathrm{F}_{\text {Time }}(4,40)=6.423 ; P=0.0004 ; \mathrm{F}_{\text {Drug }}(1,10)=0.867 ; P\right.$ $\left.=0.3738 ; \mathrm{F}_{\text {Drug } \times \text { Time }}(4,40)=1.034 ; P=0.4015\right]$.

Finally, to determine whether the effects of 1-NA-PP1 on ethanol consumption were specific for $A S$-PKC $\varepsilon$, we also investigated whether 1-NA-PP1 had an effect in wild type C57BL/ 6NTac mice that were habituated to vehicle injections and had achieved a stable baseline level of ethanol consumption for three consecutive drinking sessions $[\mathrm{F}(2,14)=1.263, P=$ 0.3132; Fig. 5A]. 1-NA-PP1 did not reduce ethanol intake $[\mathrm{F}(2,12)=0.64 ; P=0.54]$ by C57BL/6NTac mice (Fig. 5B). However, these mice consumed much less ethanol than $A S$ $\mathrm{PKC} \varepsilon$ mice, causing concern that our inability to observe an effect of 1-NA-PP1 could be do to a floor effect. Hence, we also examined ethanol consumption by C57BL/6J mice, which consume large amounts of ethanol in the continuous access paradigm (Hwa et al., 2011). Mice were habituated to vehicle injections and allowed to achieve a stable baseline level of ethanol consumption for three consecutive drinking sessions prior to administration of 1NA-PP1 $[\mathrm{F}(2,18)=2.162, P=0.1441$; Fig. $5 \mathrm{C}]$. 1-NA-PP1 caused a small increase in ethanol intake by C57BL/6J mice at the $20 \mathrm{mg} / \mathrm{kg}$ dose only $[\mathrm{F}(2,18)=6.41 ; P=0.0079$; Fig 5D]. These results demonstrate that 1-NA-PP1 does not reduce ethanol intake in two strains of wild type mice that lack the $A S$-PKC $\varepsilon$ mutation.

\subsection{1-NA-PP1 prolongs ethanol intoxication in AS-PKC $\varepsilon$ mice}

We previously found that $\mathrm{Prke}^{-/-}$mice show prolonged signs of ethanol intoxication due to impaired acute functional tolerance to ethanol (Hodge et al., 1999, Wallace et al., 2007).

Therefore, to determine if inhibiting PKC $\varepsilon$ alters ethanol intoxication, and to test whether oral administration of 1-NA-PP1 was effective in producing a phenotype, we fed $A S$-PKC $\varepsilon$ mice 1-NA-PP1 or control food and water for 11 days. On average, mice in the 1-NA-PP1 group consumed $3.00 \pm 0.14 \mathrm{~g}$ of 1-NA-PP1 food pellets/day, which was less than the amount consumed by the control group $(3.65 \pm 0.16 \mathrm{~g} /$ day; $P=0.02)$. Mice in the 1-NA-PP1 group also consumed less water $(2.00 \pm 0.01 \mathrm{ml})$ than mice in the control group $(3.5$ $\pm 0.25 \mathrm{ml}$ of control liquid /day; $P<0.0001$ ). Nevertheless, despite these differences in food and water intake, body weights were similar in 1-NA-PP1-fed $(25.5 \pm 0.18 \mathrm{~g})$ and control-fed $(25.8 \pm 0.23 \mathrm{~g})$ animals. 
Three days after the start of the feeding protocol, mice were tested for ethanol-induced ataxia (Fig. 6A). 1-NA-PP1 impaired recovery from ataxia induced by $1.5 \mathrm{~g} / \mathrm{kg}$ ethanol $\left[\mathrm{F}_{\text {Time }}(6,132)=84.60, P<0.0001 ; \mathrm{F}_{\text {Drug }}(1,22)=5.572, P=0.0275 ; \mathrm{F}_{\text {Time } \times \text { Drug }}(6,132)=\right.$ $1.618, P=0.147]$. The same cohort was tested 2 days later for ethanol-induced loss of the righting reflex (LORR) after receiving 5 days of 1-NA-PP1 in food and water. A second cohort of mice underwent the same feeding protocol for 5 days but also received an i.p. injection of $25 \mathrm{mg} / \mathrm{kg}$ 1-NA-PP1 thirty min before the test. We observed a similar effect of 1NA-PP1 in both cohorts, and therefore combined data from both. 1-NA-PP1 significantly increased the duration of the LORR induced by $3.6 \mathrm{~g} / \mathrm{kg}$ ethanol $\left(P=0.0014, \mathrm{t}_{49}=3.392 ;\right.$ Fig. $6 B)$.

To determine whether the effects of 1-NA-PP1 were specific for $A S$-PKCE, we tested the effects of 1-NA-PP1 in wild type C57BL/6NTac mice. Mice that were provided 1-NA-PP1 consumed similar amounts of food $(4.15 \mathrm{~g} \pm 0.34 \mathrm{~g} /$ day $)$ and fluid $(2.76 \pm 0.3 \mathrm{ml} /$ day $)$ as mice fed a control diet $(4.14 \pm 0.28 \mathrm{~g} /$ day and $2.4 \pm 0.21 \mathrm{ml} /$ day $)$. 1-NA-PP1 did not affect the duration of ataxia induced by $1.5 \mathrm{~g} / \mathrm{kg}$ ethanol $\left[\mathrm{F}_{\text {Time }}(4,52)=69.93, P<0.0001 ; \mathrm{F}_{\text {Drug }}(1,13)\right.$ $=0.2997 ; P=0.593 ; \mathrm{F}_{\text {Time } \times \text { Drug }}(4,52)=0.2612 ; P=0.902 ;$ Fig. $\left.6 \mathrm{C}\right]$. Likewise, the durations of the LORR induced by $3.6 \mathrm{~g} / \mathrm{kg}$ ethanol were similar in mice administered the 1-NA-PP1 diet and the control diet (Fig. 6D). These results indicate that 1-NA-PP1 has no effect on ethanol-induced ataxia or LORR in wild type mice.

\section{Discussion}

In this study, we used a chemical-genetic strategy to determine whether a potent and highly selective inhibitor of PKC $\varepsilon$ could mimic phenotypes we have observed in PKC $\varepsilon$ knockout mice, namely reduced ethanol consumption and prolonged ethanol intoxication (Hodge et al., 1999). We generated a novel $A S$-PKC $\varepsilon$ mouse line harboring a point mutation in the ATP binding site rendering it highly sensitive to inhibition by nanomolar concentrations of the PP1 analog 1-NA-PP1. Systemically administered 1-NA-PP1 crossed the blood-brain barrier and reached high enough concentrations in the brain to inhibit $A S$-PKC $\varepsilon$. 1-NA-PP1 prolonged the ataxic and hypnotic effects of ethanol and reduced ethanol consumption by $A S$-PKC $\varepsilon$ mice. These effects of 1-NA-PP1 were not observed in wild type mice lacking the $A S$-PKC $\varepsilon$ mutation. These results suggest that compounds that inhibit the catalytic activity of $\mathrm{PKC} \varepsilon$ could be useful in reducing ethanol consumption.

Pharmacokinetic analyses indicated that 1-NA-PP1 is rapidly and readily detected in the plasma and brain after parenteral administration. We also detected significant amounts of 1NA-PP1 in the brain after chronic oral administration. 1-NA-PP1 inhibited phosphorylation of the $\mathrm{GABA}_{\mathrm{A}} \gamma 2$ subunit at $\mathrm{S} 327$ in mouse striatum, indicating that 1-NA-PP1 is able to inhibit $\mathrm{PKC} \varepsilon$-mediated phosphorylation in vivo. We had previously found that $\mathrm{GABA}_{\mathrm{A}} \gamma 2$ $\mathrm{S}(\mathrm{P}) 327$ immunoreactivity is reduced by $60 \pm 6 \%$ in the frontal cortex of $\mathrm{Prkce}^{-/-}$mice (Qi et al., 2007), and phosphatase treatment did not further reduce this residual immunoreactivity, indicating that the antibody also detects dephosphorylated protein. Therefore, a $60 \%$ reduction in $\mathrm{GABA}_{\mathrm{A}} \gamma 2-\mathrm{S}(\mathrm{P}) 327$ immunoreactivity represents $100 \%$ reduction in phosphorylation at this site. Based on these results, we conclude that 
intraperitoneal administration of 25mg/kg 1-NA-PP1 reduced PKC 8 -mediated phosphorylation of $\mathrm{GABA}_{\mathrm{A}} \gamma 2$ in $A S$-PKC $\varepsilon$ mice by approximately $50 \%$.

1-NA-PP1 reduced ethanol consumption in a reversible manner, without significantly reducing alcohol preference at either of the doses tested. Although water intake was not significantly altered, there was some variability in water intake that may have masked a significant reduction in ethanol preference. At the $30 \mathrm{mg} / \mathrm{kg}$ dose, there was a trend towards reduced water consumption that was not statistically significant. Saccharin, but not quinine consumption, was significantly reduced at the $30 \mathrm{mg} / \mathrm{kg}$ dose of 1-NA-PP1. This result is different from what was observed in $\mathrm{Prkce}^{-/-}$mice (Hodge et al., 1999), which showed no deficit in saccharin consumption. It is possible that at the $30 \mathrm{mg} / \mathrm{kg}$ dose, 1-NA-PP1 reduced ethanol consumption by altering the perception of taste for sweet substances, or by effects on brain reward mechanisms or fluid intake. Of note, a reduction in saccharin and sucrose intake has been observed for naltrexone, which is FDA approved to treat alcohol use disorder (Czachowski and Delory, 2009, Ripley et al., 2015).

Baseline ethanol consumption by wild type C57BL/6NTac mice was much lower than by $A S$-PKC $\varepsilon$ mice even though both are on a C57BL/6NTac background. This difference in ethanol consumption could be due to differences in rearing environments and to genetic drift in our $A S$-PKC $\varepsilon$ colony from inbreeding. Hence, in addition to the C57BL/6NTac strain, we decided to examine the effects of 1-NA-PP1 on ethanol consumption in C57BL/6J mice, which display high intake and preference for alcohol. Importantly, 1-NA-PP1 did not reduce ethanol drinking in either strain of wild type mice, which both lack the $A S$-PKC $\varepsilon$ mutation, indicating that the effects of 1-NA-PP1 on ethanol consumption are specific for $A S$-PKC $\varepsilon$.

Our previous molecular studies suggested that $\mathrm{PKC} \varepsilon$ mediates its effects on ethanol-related behaviors by reducing inhibitory GABA neurotransmission through actions at $\mathrm{GABA}_{\mathrm{A}}$ receptors. We have identified two substrates of $\mathrm{PKC} \varepsilon$ that could contribute to decreased $\mathrm{GABA}_{\mathrm{A}}$ receptor function: the $\mathrm{GABA}_{\mathrm{A}} \gamma 2$ subunit, which when phosphorylated at $\mathrm{S} 327$ shows a reduced response to the positive allosteric effects of benzodiazepines and ethanol (Qi et al., 2007), and the N-ethylmaleimide sensitive factor, which when phosphorylated at S460 and T461 reduces the number of cell surface $\mathrm{GABA}_{\mathrm{A}}$ receptors (Chou et al., 2010). It is likely that additional $\mathrm{PKC} \varepsilon$ substrates play a role in regulating $\mathrm{GABA}_{\mathrm{A}}$ receptor function and behavioral responses to ethanol. The M486A mutation allows $A S$-PKC $\varepsilon$ to use bulky ATP analogs such as $\mathrm{N}^{6}$-benzyl-ATP as phosphate donors, while native kinases cannot use such ATP analogs (Bishop et al., 2001, Zhang et al., 2013). ATP analogs with a thiophosphate at the $\gamma$-phosphate position can generate a kinase-transferable tag, allowing use of a covalent capture-and-release method to purify tagged peptides from digests of protein mixtures (Hertz et al., 2010, Ultanir et al., 2012). Mass spectrometric analysis of these peptides reveals the identity of the corresponding proteins and the location of the phosphorylation sites. Use of this methodology with tissues from $A S$-PKCE mice could identify novel substrates of $\mathrm{PKC} \varepsilon$ in the brain that regulate $\mathrm{GABA}_{\mathrm{A}}$ receptor function and behavioral responses to ethanol in an unbiased manner. 


\section{Conclusions}

In summary, our results demonstrate that specific inhibition of $\mathrm{PKC} \varepsilon$ reduces ethanol consumption and prolongs ethanol intoxication, confirming phenotypes we have observed previously using strategies that reduce $\mathrm{PKC} \varepsilon$ expression in the brain. Our results strengthen the rationale for developing small molecule inhibitors of PKCE catalytic activity as therapeutics to decrease ethanol consumption. In addition, our findings demonstrate the utility of the $A S$-PKCE mouse as a tool for studying the role of PKC $\varepsilon$ in behavior and for identifying direct substrates of PKCE.

\section{Acknowledgments}

This work was supported by NIH grants AA13588 and AA017072, and by funds provided by the State of California for medical research for alcohol and substance abuse through UCSF to R.O.M. We thank Michael Cameron and the DMPK core at Scripps Florida and Yong Huang and the Drug Studies Unit, Analytical Division, UCSF College of Pharmacy for their work on the pharmacokinetics and tissue measurement of 1-NA-PP1.

\section{References}

Bishop AC, Buzko O, Shokat KM. Magic bullets for protein kinases. Trends Cell Biol. 2001; 11:167172. [PubMed: 11306297]

Carnicella S, Ahmadiantehrani S, Janak PH, Ron D. GDNF is an endogenous negative regulator of ethanol-mediated reward and of ethanol consumption after a period of abstinence. Alcohol Clin Exp Res. 2009; 33:1012-1024. [PubMed: 19302086]

Choi DS, Wang D, Dadgar J, Chang WS, Messing RO. Conditional rescue of protein kinase C epsilon regulates ethanol preference and hypnotic sensitivity in adult mice. J Neurosci. 2002; 22:99059911. [PubMed: 12427847]

Chou WH, Wang D, McMahon T, Qi ZH, Song M, Zhang C, Shokat KM, Messing RO. GABAA receptor trafficking is regulated by protein kinase $\mathrm{C}$ (epsilon) and the N-ethylmaleimide-sensitive factor. J Neurosci. 2010; 30:13955-13965. [PubMed: 20962217]

Cozzoli DK, Courson J, Rostock C, Campbell RR, Wroten MG, McGregor H, Caruana AL, Miller BW, Hu JH, Wu Zhang P, Xiao B, Worley PF, Crabbe JC, Finn DA, Szumlinski KK. Protein kinase $\mathrm{C}$ epsilon activity in the nucleus accumbens and central nucleus of the amygdala mediates binge alcohol consumption. Biol Psychiatry. 2015

Crawley JN. Behavioral phenotyping strategies for mutant mice. Neuron. 2008; 57:809-818. [PubMed: 18367082]

Czachowski CL, Delory MJ. Acamprosate and naltrexone treatment effects on ethanol and sucrose seeking and intake in ethanol-dependent and nondependent rats. Psychopharmacology (Berl). 2009; 204:335-348. [PubMed: 19153715]

Durgan J, Cameron AJ, Saurin AT, Hanrahan S, Totty N, Messing RO, Parker PJ. The identification and characterization of novel PKCepsilon phosphorylation sites provide evidence for functional cross-talk within the PKC superfamily. Biochem J. 2008; 411:319-331. [PubMed: 18237277]

Hertz NT, Wang BT, Allen JJ, Zhang C, Dar AC, Burlingame AL, Shokat KM. Chemical genetic approach for kinase-substrate mapping by covalent capture of thiophosphopeptides and analysis by mass spectrometry. Curr Protoc Chem Biol. 2010; 2:15-36. [PubMed: 23836541]

Hodge CW, Mehmert KK, Kelley SP, McMahon T, Haywood A, Olive MF, Wang D, Sanchez-Perez AM, Messing RO. Supersensitivity to allosteric GABA(A) receptor modulators and alcohol in mice lacking PKCepsilon. Nat Neurosci. 1999; 2:997-1002. [PubMed: 10526339]

Hodge CW, Raber J, McMahon T, Walter H, Sanchez-Perez AM, Olive MF, Mehmert K, Morrow AL, Messing RO. Decreased anxiety-like behavior, reduced stress hormones, and neurosteroid supersensitivity in mice lacking protein kinase Cepsilon. J Clin Invest. 2002; 110:1003-1010. [PubMed: 12370278] 
Hwa LS, Chu A, Levinson SA, Kayyali TM, DeBold JF, Miczek KA. Persistent escalation of alcohol drinking in C57BL/6J mice with intermittent access to 20\% ethanol. Alcohol Clin Exp Res. 2011; 35:1938-1947. [PubMed: 21631540]

Johnson BA. Update on neuropharmacological treatments for alcoholism: scientific basis and clinical findings. Biochem Pharmacol. 2008; 75:34-56. [PubMed: 17880925]

Lee AM, Kanter BR, Wang D, Lim JP, Zou ME, Qiu C, McMahon T, Dadgar J, Fischbach-Weiss SC, Messing RO. Prkcz null mice show normal learning and memory. Nature. 2013; 493:416-419. [PubMed: 23283171]

Lee AM, Zou ME, Lim JP, Stecher J, McMahon T, Messing RO. Deletion of Prkcz increases intermittent ethanol consumption in mice. Alcohol Clin Exp Res. 2014; 38:170-178. [PubMed: 23905844]

Lesscher HM, Wallace MJ, Zeng L, Wang V, Deitchman JK, McMahon T, Messing RO, Newton PM. Amygdala protein kinase C epsilon controls alcohol consumption. Genes Brain Behav. 2009; 8:493-499. [PubMed: 19243450]

Lim JP, Zou ME, Janak PH, Messing RO. Responses to ethanol in C57BL/6 versus C57BL/6 × 129 hybrid mice. Brain Behav. 2012; 2:22-31. [PubMed: 22574271]

Newton PM, Messing RO. Increased sensitivity to the aversive effects of ethanol in PKCepsilon null mice revealed by place conditioning. Behav Neurosci. 2007; 121:439-442. [PubMed: 17469934]

Qi ZH, Song M, Wallace MJ, Wang D, Newton PM, McMahon T, Chou WH, Zhang C, Shokat KM, Messing RO. Protein kinase $\mathrm{C}$ epsilon regulates gamma-aminobutyrate type A receptor sensitivity to ethanol and benzodiazepines through phosphorylation of gamma2 subunits. J Biol Chem. 2007; 282:33052-33063. [PubMed: 17875639]

Rehm J, Mathers C, Popova S, Thavorncharoensap M, Teerawattananon Y, Patra J. Global burden of disease and injury and economic cost attributable to alcohol use and alcohol-use disorders. Lancet. 2009; 373:2223-2233. [PubMed: 19560604]

Ripley TL, Sanchez-Roige S, Bullmore ET, Mugnaini M, Maltby K, Miller SR, Wille DR, Nathan P, Stephens DN. The novel mu-opioid antagonist, GSK1521498, reduces ethanol consumption in C57BL/6J mice. Psychopharmacology (Berl). 2015

Schneider CA, Rasband WS, Eliceiri KW. NIH Image to ImageJ: 25 years of image analysis. Nat Methods. 2012; 9:671-675. [PubMed: 22930834]

Ultanir SK, Hertz NT, Li G, Ge WP, Burlingame AL, Pleasure SJ, Shokat KM, Jan LY, Jan YN. Chemical genetic identification of NDR1/2 kinase substrates AAK1 and Rabin8 Uncovers their roles in dendrite arborization and spine development. Neuron. 2012; 73:1127-1142. [PubMed: 22445341]

Wallace MJ, Newton PM, Oyasu M, McMahon T, Chou WH, Connolly J, Messing RO. Acute functional tolerance to ethanol mediated by protein kinase Cepsilon. Neuropsychopharmacology. 2007; 32:127-136. [PubMed: 16541084]

Zhang C, Lopez MS, Dar AC, Ladow E, Finkbeiner S, Yun CH, Eck MJ, Shokat KM. Structure-guided inhibitor design expands the scope of analog-sensitive kinase technology. ACS Chem Biol. 2013; 8:1931-1938. [PubMed: 23841803] 


\section{Highlights}

- $\quad$ Novel knock-in $A S$-PKC $\varepsilon$ mice were generated with an ATP analogspecific gatekeeper mutation in the purine-binding site of PKC $\varepsilon$.

- $\quad$ Administration of the selective $A S$-kinase inhibitor 1-NA-PP1 to $A S$-PKCE mice reduced their ethanol consumption.

- $\quad$ Administration of 1-NA-PP1 to $A S$-PKC $\varepsilon$ mice prolonged ethanol intoxication.

- Selective inhibitors of PKC $\varepsilon$ catalytic activity may prove useful for decreasing ethanol consumption. 
A

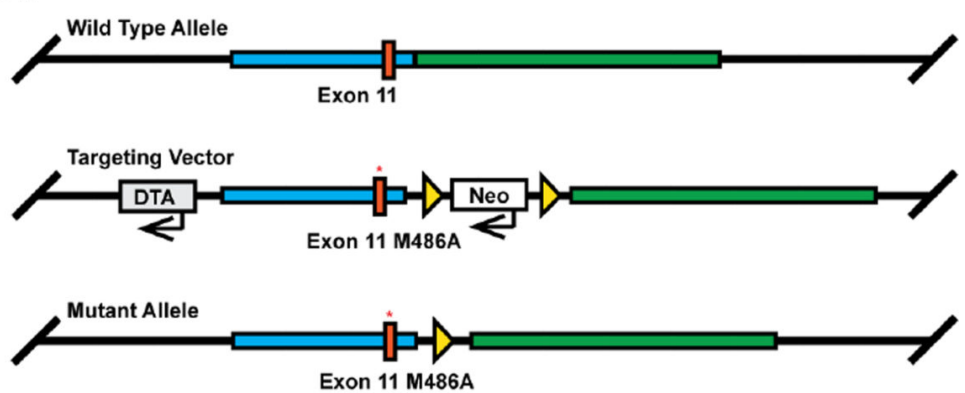

B

$A / A$ A $/ A+/ A+/++/+$

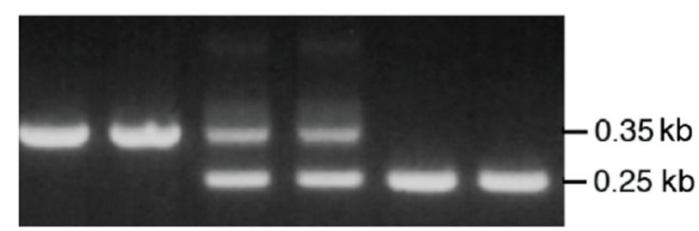

C

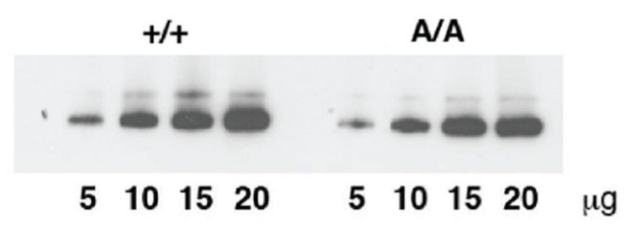

D
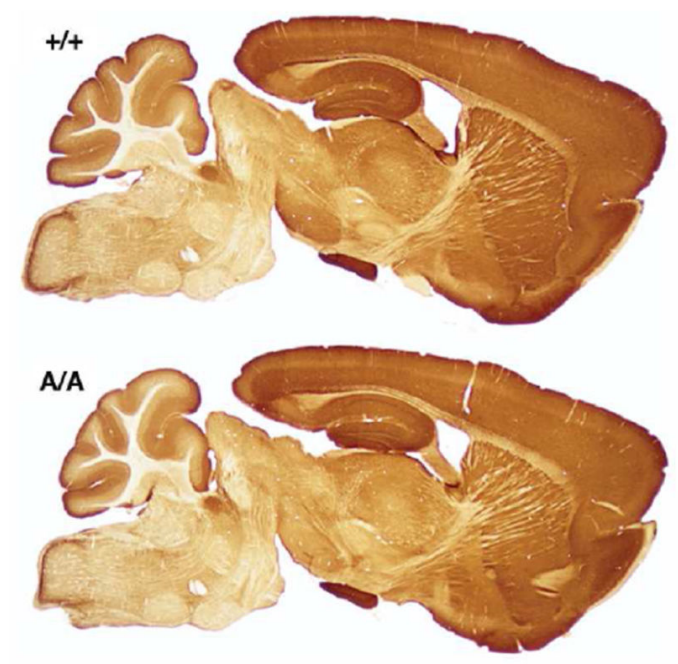

Fig. 1.

Generation of $A S$-PKC $\varepsilon$ knock-in mice. (A) Schematic showing targeting strategy for generating the M486A mutation (red asterisk) in exon 11 of the mouse Prkce gene. DTA = diphtheria toxin A expression cassette for negative selection; $\mathrm{Neo}=$ neomycin expression cassette for positive selection. Triangles represent loxP sites for Cre-recombinase mediated excision of the Neo cassette in embryonic stem cell clones. (B) PCR of tail DNA demonstrated presence of mutant (A) and wild type (+) alleles. (C) Western blot analysis showed similar levels of PKC $\varepsilon$ immunoreactivity in $A S$-PKC $\varepsilon(\mathrm{A} / \mathrm{A})$ and wild type (+/+) 
hippocampus. (D) The distribution of brain PKC $\varepsilon$ immunoreactivity was similar in $A S$ $\mathrm{PKC} \varepsilon(\mathrm{A} / \mathrm{A})$ and wild type $(+/+)$ mice. 

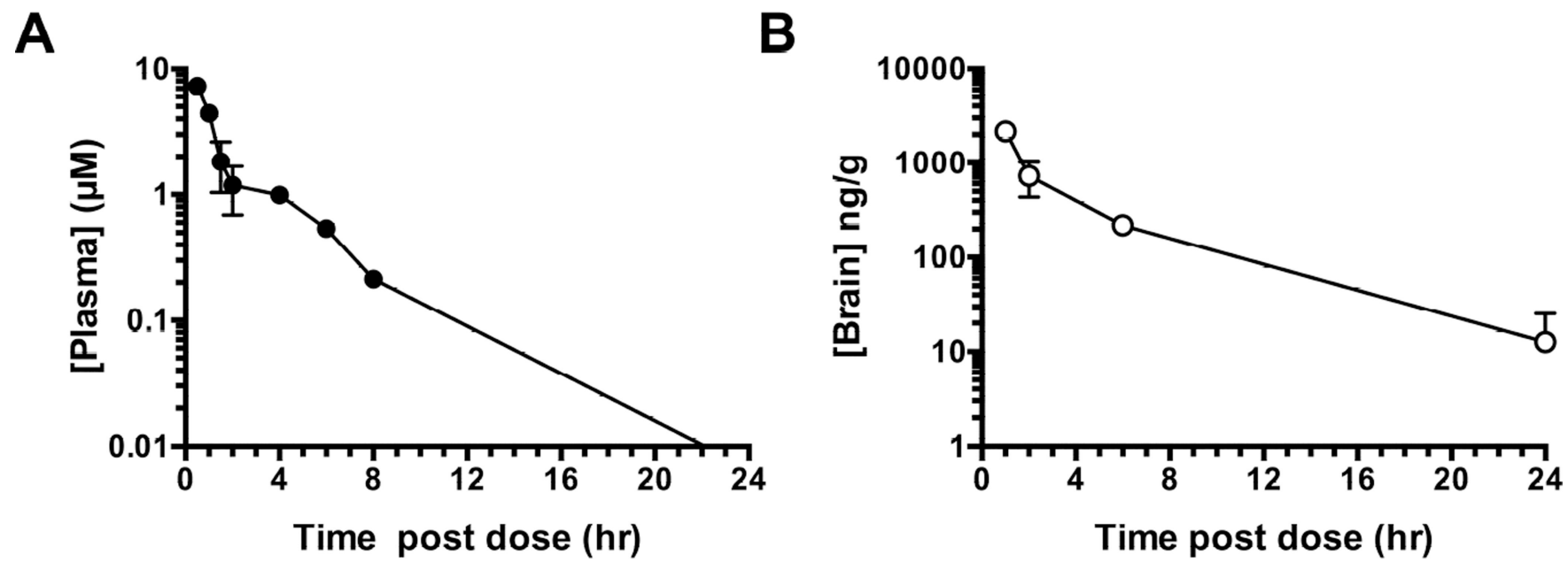

Fig. 2.

1-NA-PP1 pharmacokinetics after intraperitoneal injection of 30mg/kg 1-NA-PP1. Data shown are (A) plasma and (B) brain concentrations of 1-NA-PP1, with $n=3$ for each data point. 

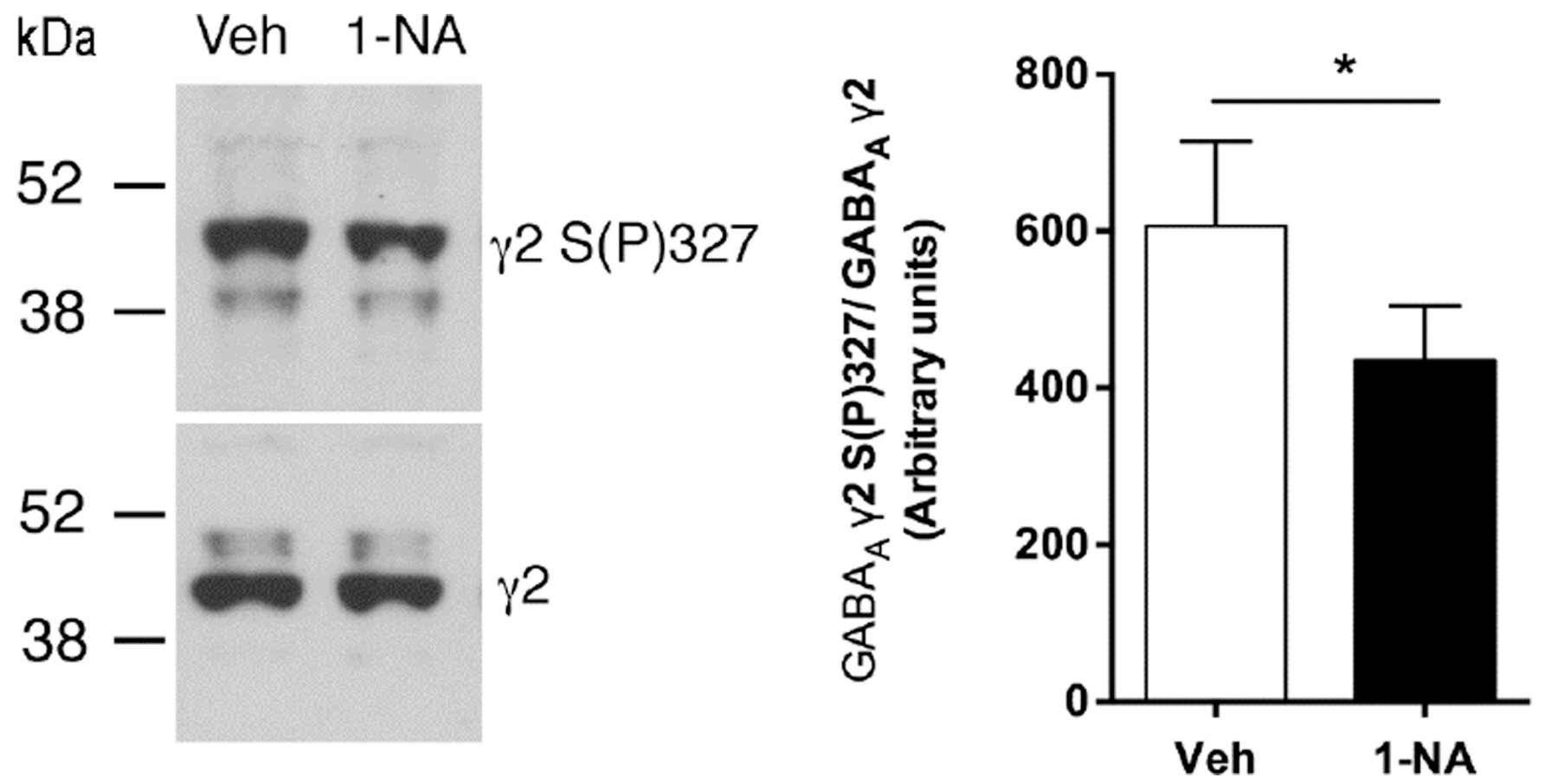

Fig. 3.

$\mathrm{GABA}_{\mathrm{A}} \gamma 2$ receptor subunit phosphorylation. Intraperitoneal injection of $25 \mathrm{mg} / \mathrm{kg} 1$-NAPP1 decreased $\mathrm{GABA}_{\mathrm{A}} \gamma 2-\mathrm{S}(\mathrm{P}) 327$ immunoreactivity compared with vehicle. Left panel shows representative western blots for anti $\mathrm{GABA}_{\mathrm{A}} \gamma 2 \mathrm{~S}(\mathrm{P}) 327$ immunoreactivity (top) and total $\mathrm{GABA}_{\mathrm{A}} \gamma 2$ immunoreactivity (bottom) from the same vehicle (Veh)- and 1-NA-PP1 (1NA)-treated samples. Right panel shows mean \pm S.E.M. results from all animals. ${ }^{*} P=$ $0.0175, \mathrm{t}(8)=2.98$, two-tailed, unpaired $t$-test $n=5$ per group. 
A

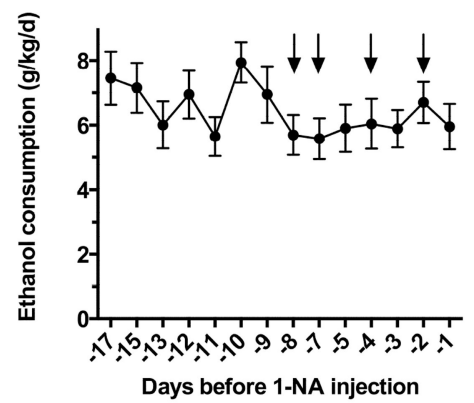

C

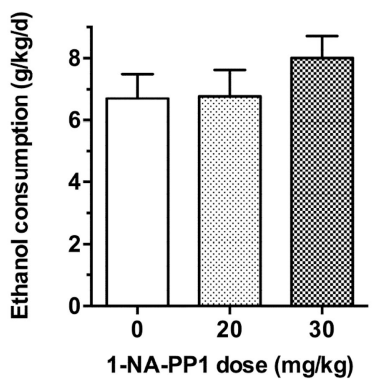

$\mathbf{E}$

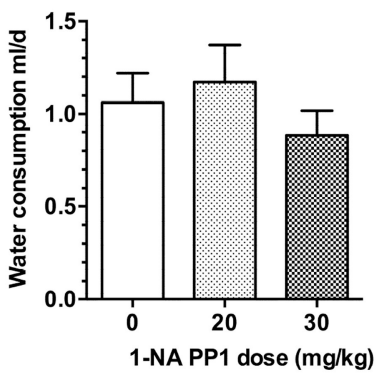

$\mathbf{G}$

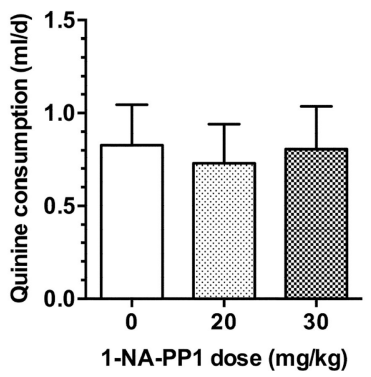

B

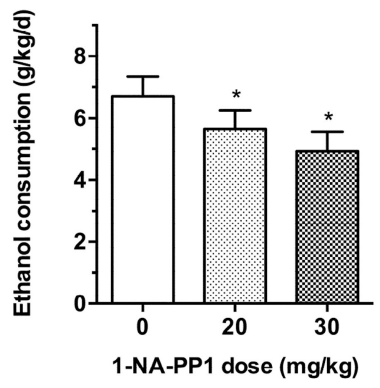

D

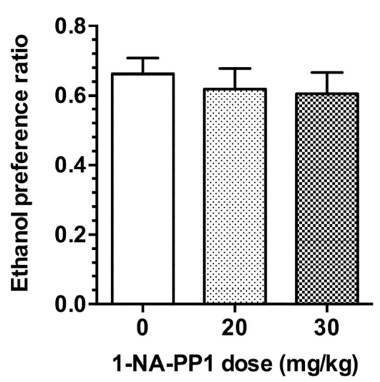

$\mathbf{F}$

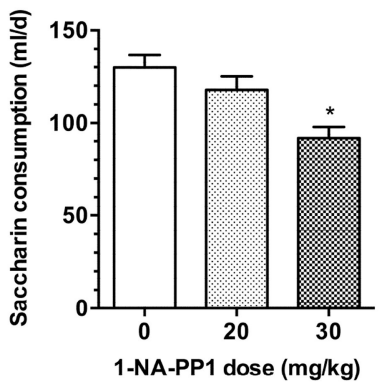

H

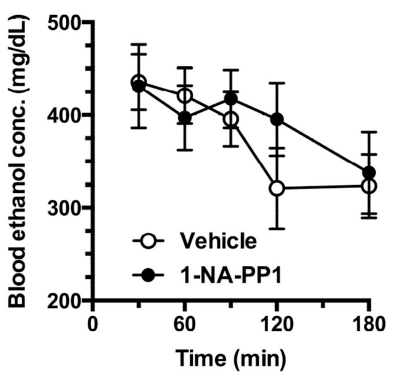

Fig. 4.

Ethanol consumption by $A S$-PKC $\varepsilon$ mice. (A) $A S$-PKC $\varepsilon$ mice were habituated to vehicle injections and allowed to achieve a stable baseline level of drinking. Arrows point to days when animals received vehicle injections. 1-NA-PP1 reduced ethanol consumption (B) and this effect was reversible since it was no longer present 48 hours after administration of 1NA-PP1 (C). (D) 1-NA-PP1 did not alter preference for ethanol over water or water intake (E) 1-NA-PP1 $(30 \mathrm{mg} / \mathrm{kg})$ reduced saccharin intake $(\mathrm{F})$, but not quinine $(\mathrm{G})$ intake.(H) 1- 
NA-PP1 $(30 \mathrm{mg} / \mathrm{kg})$ did not alter ethanol clearance. ${ }^{*} P<0.05$, Dunnett's test; $n=18$ per group (A-E), $n=14$ per group (F and G), $n=7$ per group $(\mathrm{H})$. 
A

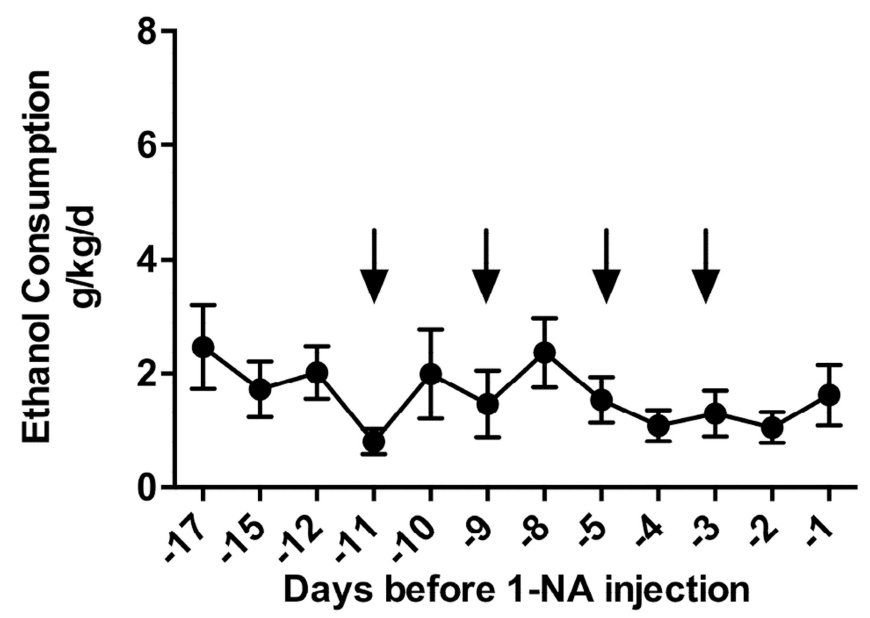

C
B

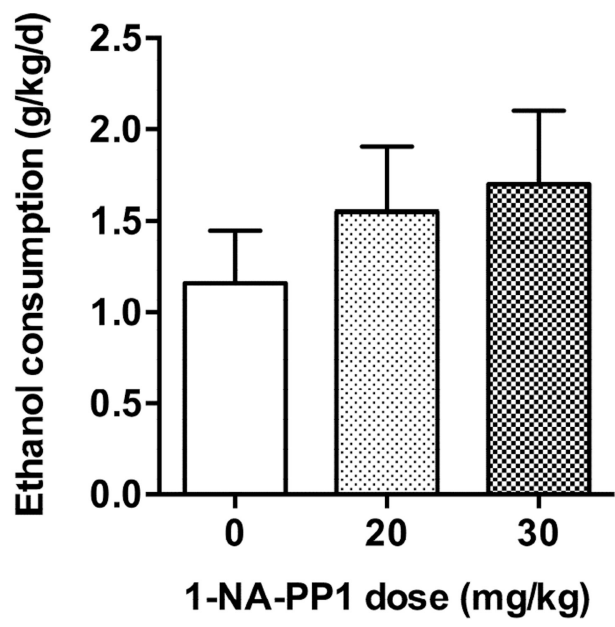

D

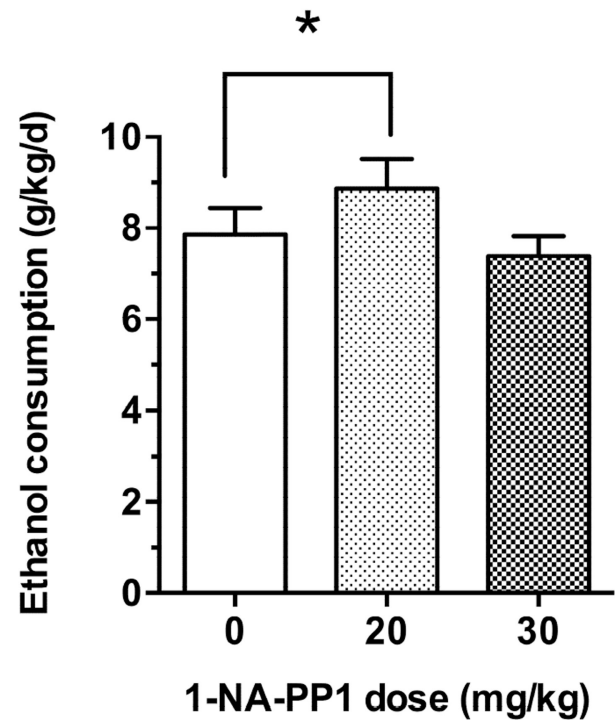

Fig. 5.

Ethanol consumption by wild type mice. (A) C57BL/6NTac mice were habituated to vehicle injections and stable baseline drinking was attained prior to administration of 1-NA-PP1.

Arrows point to days when animal received vehicle injections. (B) Administration of 1-NAPP1 did not significantly alter drinking by C57BL/6NTac mice ( $n=7$ per group). (A) $\mathrm{C} 57 \mathrm{BL} / 6 \mathrm{~J}$ mice were habituated to vehicle injections and stable baseline drinking was attained prior to administration of 1-NA-PP1. Arrows point to sessions when animals received vehicle injections. (B) 1-NA-PP1 produced a small but significant increase in ethanol consumption in C57BL/6J mice at $20 \mathrm{mg} / \mathrm{kg}$, but not at $30 \mathrm{mg} / \mathrm{kg}$ ( $n=10$ per group). $* P<0.05$, Dunnett's test. 

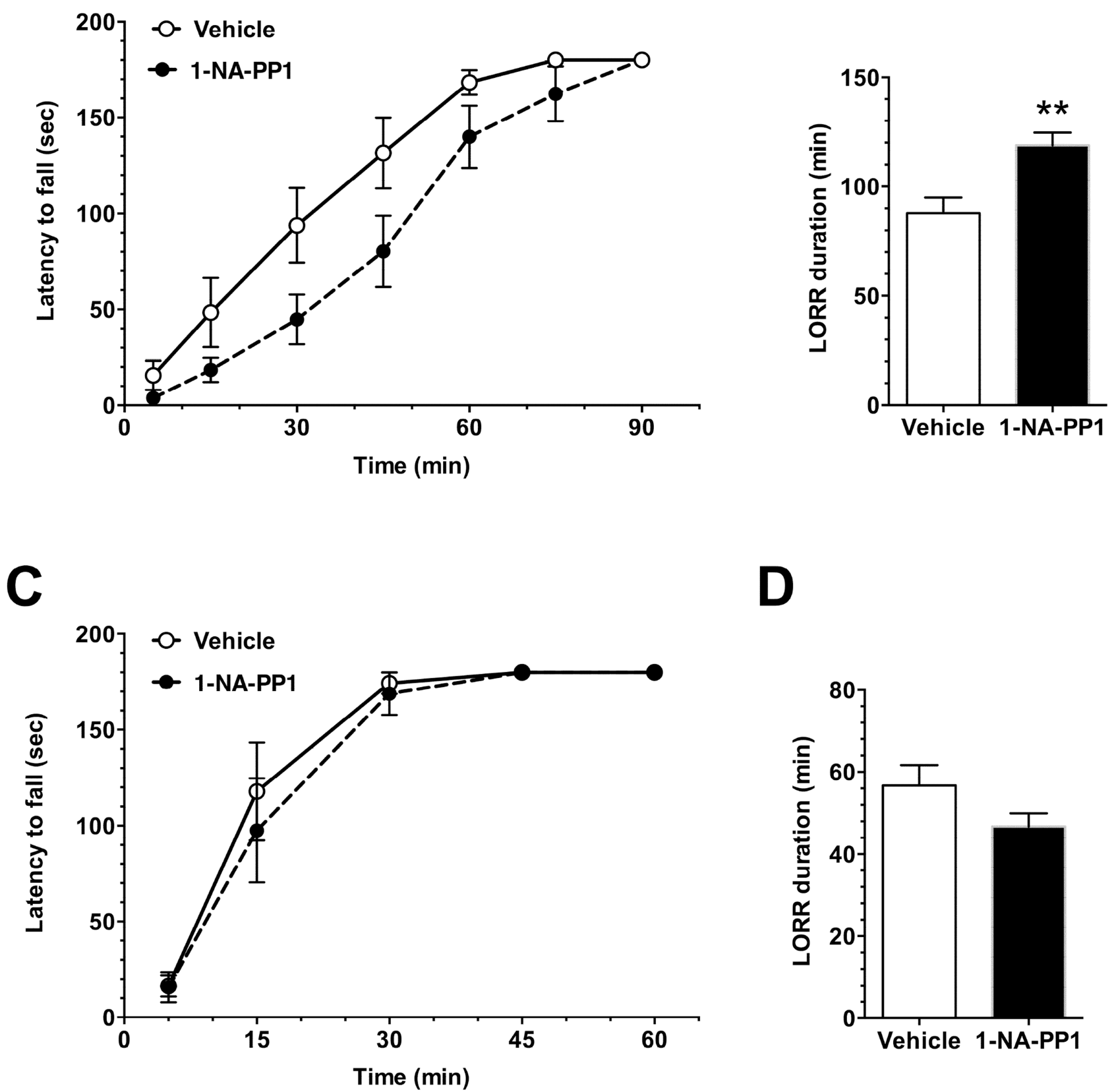

D

Fig. 6.

Ethanol-induced ataxia and LORR. In $A S$-PKCE mice, $30 \mathrm{mg} / \mathrm{kg} 1-\mathrm{NA}-\mathrm{PP} 1$ prolonged recovery from ataxia induced by $1.5 \mathrm{~g} / \mathrm{kg}$ ethanol; $n=11$ (vehicle), $n=13$ (1-NA-PP1). (B) In $A S$-PKC $\varepsilon$ mice, 1-NA-PP1 also increased the duration of LORR induced by $3.6 \mathrm{~g} / \mathrm{kg}$ ethanol; $n=25$ (vehicle), $n=26$ (1-NA-PP1). (C) In wild type mice, 1-NA-PP1 did not alter recovery from ataxia induced by $1.5 \mathrm{~g} / \mathrm{kg}$ ethanol; $n=8$ (vehicle), $n=7$ (1-NA-PP1). (D) In 
wild type mice, 1-NA-PP1 also did not alter the duration of the LORR induced by $3.6 \mathrm{~g} / \mathrm{kg}$ ethanol ( $n=8$ per group). $* P=0.0014, \mathrm{t}_{49}=3.392$, two-tailed, unpaired $t$-test. 


\section{Table 1}

Baseline behaviors are similar in wild type and $A S$-PKC $\varepsilon$ mice

\begin{tabular}{lrrl}
\hline Test (males, age P75-P165) & Wild type $(\boldsymbol{n})$ & $\boldsymbol{A S}$-PKC $\varepsilon(\boldsymbol{n})$ & $\boldsymbol{P}$ value \\
\hline Weight (g) at age P90-P120 & $27.76 \pm 0.92(10)$ & $26.43 \pm 0.56(7)$ & 0.289 \\
Wire suspension fall latency (sec) & $111.7 \pm 30.7(10)$ & $74.3 \pm 37.6(7)$ & 0.450 \\
Accelerating rotarod fall latency (sec) & $56.1 \pm 4.8(19)$ & $64.1 \pm 4.2(7)$ & 0.350 \\
Open field total distance (cm) & $6292 \pm 462.9(8)$ & $5532 \pm 733.5(7)$ & 0.319 \\
Open field \% time in center & $22.4 \pm 3.9(8)$ & $21.8 \pm 4.6(7)$ & 0.929 \\
Elevated plus maze (5 min) & & & \\
\% Open time & $41.0 \pm 9.4(10)$ & $38.3 \pm 10.9(7)$ & 0.858 \\
\% Open entries & $43.9 \pm 5.5(10)$ & $43.4 \pm 7.6(7)$ & 0.959 \\
\# Closed entries & $11.9 \pm 1.1(10)$ & $15.0 \pm 2.0(7)$ & 0.158 \\
Hot plate latency at 56 ${ }^{\circ} \mathrm{C}(\mathrm{sec})$ & $5.80 \pm 0.27(8)$ & $6.01 \pm 0.34(7)$ & 0.640 \\
\hline
\end{tabular}

